\title{
Student's Participation In Extracuricular School Sports Has Positive Impact On Executive Functions
}

\author{
Misbah Abdul Haris Nasution Alhanif ${ }^{1}$, Purwo Sri Rejeki ${ }^{12}$, and Lilik Herawati ${ }^{12 *}$ \\ ${ }^{I}$ Sport Health Science Study Program, Faculty of Medicine Universitas Airlangga, Indonesia \\ ${ }^{2}$ Department of Physiology, Faculty of Medicine Universitas Airlangga, Indonesia \\ *lilik_heraw@fk.unair.ac.id
}

\begin{abstract}
Children aged 4-6 years are the golden age to be given stimulation of executive function and motor function. This study aims to analyze the differences in motor function and executive function in students who take sports extracurricular activities and non-sports extracurricular activities. This study used a cross sectional case control study method using 52 students aged 4-6 years, body mass index (BMI) $14.0-16.0 \mathrm{~kg} / \mathrm{m}^{2}$ and randomly divided into two groups, namely EO ( $n=26$, sports extracurricular activities) and $\mathrm{EBO}(\mathrm{n}=26$, nonsports extracurricular activities). The Audio and Visual Whole Body Reaction (WBR) motor function test uses the THP-15 tool, the balance test uses the Balance Error Scoring System (BESS), while the Working Memory (WM) executive function test uses the Forward Digit Span Task and the Inhibitory Control (IC) test using the Animal Stroop Task. The data analysis technique used the Pearson Chi-Square test with Statistical Package for Social Science (SPSS). The results obtained the mean of the visual Whole Body Reaction (WBR) motor function in the EO $(0.55 \pm 0.21)$ and EBO $(0.52 \pm 0.25)$ groups $(\mathrm{p}=0.558)$. The mean WBR Audio in the EO $(0.73 \pm 0.24)$ and EBO $(0.70 \pm 0.29)$ groups $(\mathrm{p}=0.918)$. The average balance in the EO group (1.65 \pm 0.54$)$ and EBO $(1.58 \pm 0.48)$ $(\mathrm{p}=0.297)$. Executive function of Working Memory (WM) in the EO activities. Extracurricular sports in schools have a positive impact on executive functioning $(5.00 \pm 0.74)$ and EBO $(5.19 \pm 0.74)$ groups $(\mathrm{p}=0.636)$. The mean inhibitory control (IC) in the EO group (4.61 \pm 2.09$)$ and the EBO group $(3.88 \pm 2.86)(\mathrm{p}=0.048)$. Based on the results of the study, it can be concluded that students who take extracurricular sports at school have higher executive inhibitory control function than students who take nonsports extracurricular.
\end{abstract}

Keywords : Sports Extracurricular, Motor Function, Executive Function 


\section{STRADA Jurnal Ilmiah Kesehatan}

DOI: $10.30994 /$ sjik.v9i2.424

ISSN: 2252-3847 (print); 2614-350X (online)

Vol.9 No.2 November 2020 Page.1047-1055

\section{BACKGROUND}

Children in Indonesia and other countries are currently experiencing enormous challenges due to the advancement of technology, children under 8 years of age, in this case pre-school children, play more on smartphones, compared to physical activity. Abramson 2009 reported that children who use cell phones more in one week experience worse inhibitory control, poor memory performance accuracy and faster in completing tasks but are not accurate (Abramson et al., 2009).

In addition to impaired executive function, it also affects motor disorders, motor coordination disorders or what is known as dyspraxia / Developmental Coordination Disorder (DCD). The estimated prevalence of dyspraxia is around $10 \%$, of which $2 \%$ is more severe (Gibbs et al., 2007). It is estimated that one child in each class has DCD. The World Health Organization reports the prevalence of inactivity in children under 11 years reached $81 \%$ in 2010 and is predicted to continue to increase along with the development of technology and economic progress in a country.

The age of pre-school children is 4-6 years (Education, Culture, \& Indonesia, 2014; Range, Childhood, Childhood, \& Setting, 2011). Age 6 years is the second peak of brain growth (Epstein \& Ma, 1986). The motor sensations in the large muscles begin to be active and can be stimulated, the brain volume approaches the maximum and is ready to stimulate executive functions such as self-inhibition (emotional control, resisting temptation, refusing to act impulsively), brain memory in terms of memory, and cognitive flexibility (think critically and see a problem from several points of view, flexible in thinking and easy to adapt to circumstances) (Diamond, 2014).

Executive function is part of cognitive function which includes inhibitory control (ability to control yourself), working memory (ability to store information) and cognitive flexibility (ability to think flexibly) which is very important in life such as self-control, planning in making decisions, memory performance in remembering and processing information (Diamond, 2014). Of the three executive functions, working memory and selfcontrol are very important in interacting with the child's environment day and night (Simpson \& Riggs, 2005). Motor function related to the ability to walk, run, balance, and reaction speed are closely related to quality of life, because children who experience weakness in motor function will result in lack of physical activity, lack of play, and laziness to move, which has an impact on decreased health (Adamo et al., 2016).

Good motor function correlates with good executive function (Zeng et al., 2017a), 3 year old infants who have good gross and fine motor skills have good cognitive inhibition (self-control) abilities (Wu et al., 2017). Sport has a positive impact on motor skills as well as one's executive function (Adamo et al., 2016; Gibbs et al., 2007). The correlation between sports activities in children is very important to note.

In addition to having an effect on executive function, sport can also improve motor function development (Zeng et al., 2017), such as tests on standing on one leg, coordination of sitting and standing movements (Barnett et al., 2016; Bellows et al., 2013; Goldfield et al., 2012). The mechanisms for increasing executive function include increased Growth Hormone (GH) and increased Brain-Derived Neurotrophic Factor (BDNF), which plays a role in increasing synaptic plasticity (Nyberg \& Hallberg, 2013). The role of GH is in the learning and memories process and BDNF plays a role in Long term potentiation (LTP) which also plays a role in memory storage in the hippocampus (Novkovic et al., 2015; Nyberg \& Hallberg, 2013).

The correlation between motor function and executive function with physical activity in previous studies shows a very related result, but the correlation between the age of pre- 


\section{STRADA Jurnal Ilmiah Kesehatan}

DOI: $10.30994 /$ sjik.v9i2.424

ISSN: 2252-3847 (print); 2614-350X (online)

Vol.9 No.2 November 2020 Page.1047-1055

school children is not known. Therefore, research to reveal the differences between several motor and executive functions in pre-school children who choose sports and non-sports extracurricular activities is necessary.

\section{METHOD}

This study used a cross sectional case control study method using 52 subjects of Raudlotul Athfal (RA) Al Hidayah students, Prambon District, Nganjuk Regency, ages 4-6 years, body mass index (BMI) $14.0-16.0 \mathrm{~kg} / \mathrm{m}^{2}$ and randomly. divided into two groups, namely EO ( $n=26$, sports extracurricular) and EBO $(n=26$, non-sports extracurricular activities). All research procedures have been approved by the Health Research Ethics Commission of the Faculty of Medicine, Airlangga University, Surabaya number 70/EC/KEPK/FKUA/2020.

The Whole Body Reaction (WBR) motor function test uses the THP 15 tool. The balance test uses the Balance Error Scoring System (BESS), which is a static balance test standing on one leg with open eyes (Miyatake et al., 2012). The Working Memory (WM) executive function test uses the forward digit span test. Using visuospatial digit span task and recall digit span task, which is a test to remember numbers using slide power points. Inhibitory control tests using the Animal Stroop test. That is, there are 20 cards with pictures (chicken, duck, goat, cow), black and white animal pictures with cartoon designs with head designs with incongruent bodies, for example the body of a cow, a chicken's head, a chicken's head. Subjects were asked to name the animal based on the animal's body (Henry \& Bettenay, 2010).

The data analysis technique used descriptive test and Pearson Chi-Square test with Statistical Package for Social Science (SPSS) version 21 (Chicago, IL, USA). All data are presented as mean \pm SD.

\section{RESULTS}

Characteristics of Research Subjects

Table 1. Characteristics of RA Al Hidayah Students

\begin{tabular}{lll}
\hline Parameter & EO $(\mathbf{n}=\mathbf{2 6})$ & EBO $(\mathbf{n}=\mathbf{2 6})$ \\
\hline \multirow{2}{*}{ Gender } & 16 female & 12 female \\
& 10 male & 14 male \\
\hline Age $($ year $)$ & $6.46 \pm 0.50$ & $6.46 \pm 0.50$ \\
\hline BMI $\left(\mathrm{kg} / \mathrm{m}^{2}\right)$ & $14.66 \pm 1.94$ & $15.03 \pm 2.37$ \\
\hline
\end{tabular}

Note: EO: Sports Extracurricular; EBO: Non-Sports Extracurricular; BMI: Body Mass Index. All data are presented as mean \pm SD.

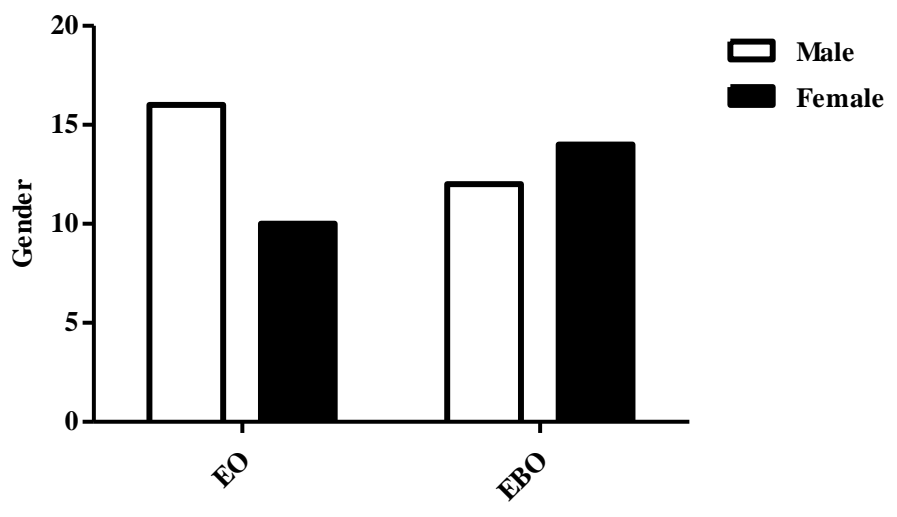




\section{STRADA Jurnal Ilmiah Kesehatan}

DOI: $10.30994 /$ sjik.v9i2.424

ISSN: 2252-3847 (print); 2614-350X (online)

Vol.9 No.2 November 2020 Page.1047-1055

Figure 1. Gender in Each Group
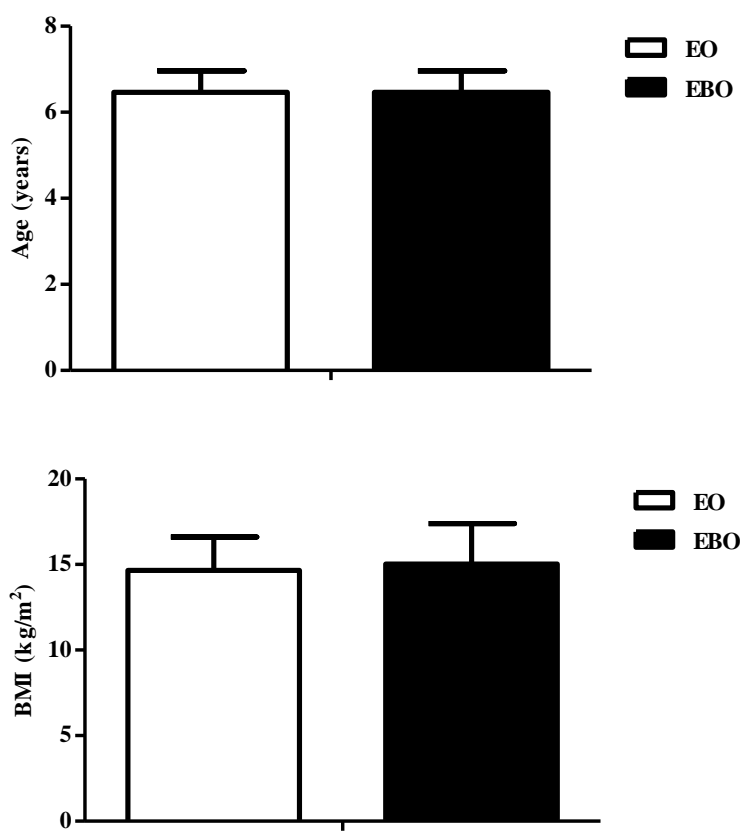

Figure 2. Mean Age and BMI in Each Group

Based on Table 1 and Figure 1-2 shows that the mean age in each group is $6.46 \pm 0.50$ years. This age is in accordance with the curriculum of the 2014 Minister of Education and Culture (Permendikbud) of the Republic of Indonesia regarding pre-school aged children, namely 4-6 years (Permendikbud, 2014). BMI data shows that the mean of the sports extracurricular group $(14.66 \pm 1.94) \mathrm{kg} / \mathrm{m}^{2}$ and the mean BMI for non-sports extracurricular activities $(15.03 \pm 2.37) \mathrm{kg} / \mathrm{m}^{2}$. According to WHO (2007), it explains that BMI is a BMI with a normal category (WHO, 2007). The results of the analysis of the mean motor function and executive function in each group can be seen in Table 2 and Figure 3.

\section{Difference in mean motor function and executive function}

Table 2. Differences in mean motor function and executive function in each group

\begin{tabular}{lcc}
\hline Parameter & EO $(\mathbf{n = 2 6})$ & EBO $(\mathbf{n = 2 6})$ \\
Whole body reaction (WBR) & & \\
Visual & $0.55 \pm 0.21$ & $0.52 \pm 0.25$ \\
Audio & $0.73 \pm 0.24$ & $0.70 \pm 0.29$ \\
\hline Balance & $1.65 \pm 0.54$ & $1.58 \pm 0.48$ \\
\hline Working Memory (WM) & $5.00 \pm 0.74$ & $5.19 \pm 0.74$ \\
\hline Inhibitory Control (IC) & $4.61 \pm 2.09$ & $3.88 \pm 2.86$
\end{tabular}

Note: All data are presented as mean \pm SD. 


\section{STRADA Jurnal Ilmiah Kesehatan}

DOI: $10.30994 /$ sjik.v9i2.424

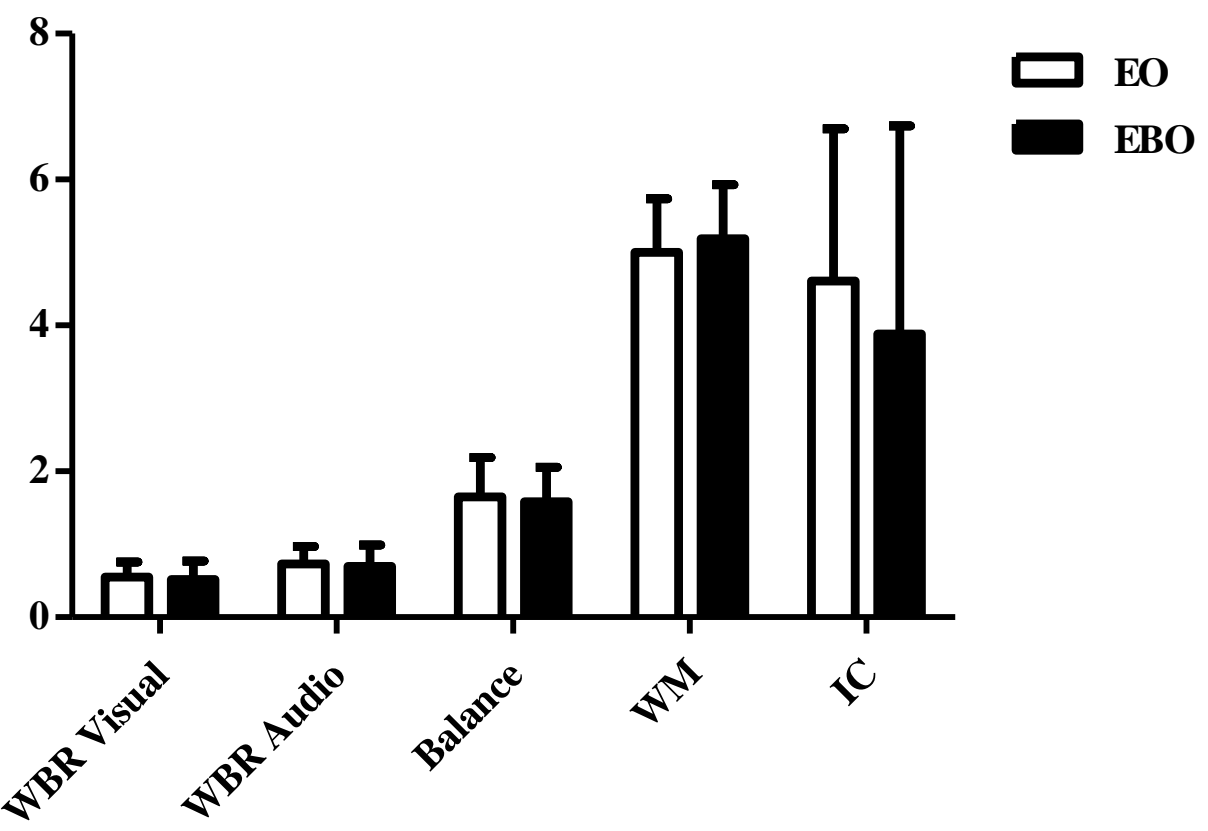

Figure 3. Average Motor Functions and Executive Functions in Each Group

Based on Table 2 and Figure 3, it shows that the mean motor function of the Whole Body Reaction (WBR) Visual in the EO group $(0.55 \pm 0.21)$ was higher than that in the EBO group $(0.52 \pm 0.25)$. The average WBR Audio in the EO group $(0.73 \pm 0.24)$ was higher than that of the EBO group $(0.70 \pm 0.29)$. The EO group $(1.65 \pm 0.54)$ had a higher mean balance than the EBO group (1.58 \pm 0.48$)$. The Executive Function of Working Memory $(\mathrm{WM})$ in the EO group (5.00 \pm 0.74$)$ was lower than that of the EBO group $(5.19 \pm 0.74)$. The results of the analysis of the mean inhibitory control (IC) in the EO group (4.61 \pm 2.09$)$ were higher than the EBO group (3.88 \pm 2.86$)$.

Differences in categories of motor functions and executive functions

Table 3. Different categories of motor functions and executive functions

\begin{tabular}{|c|c|c|c|c|}
\hline & \multicolumn{3}{|c|}{ Audio WBR (kategori) } & \multirow{2}{*}{ Pearson Chi-Square } \\
\hline Group & More & Moderate & Less & \\
\hline $\mathrm{EO}$ & 3 & 19 & 4 & \multirow{2}{*}{0.558} \\
\hline EBO & 5 & 19 & 2 & \\
\hline \multicolumn{5}{|c|}{ Visual WBR (kategori) } \\
\hline $\mathrm{EO}$ & 5 & 17 & 4 & \multirow{2}{*}{0.918} \\
\hline EBO & 5 & 18 & 3 & \\
\hline \multicolumn{5}{|c|}{ Balance } \\
\hline $\mathrm{EO}$ & 3 & 21 & 2 & \multirow{2}{*}{0.297} \\
\hline EBO & 2 & 18 & 6 & \\
\hline \multicolumn{5}{|c|}{ Working Memory } \\
\hline EO & 7 & 12 & 7 & \multirow{2}{*}{0.636} \\
\hline EBO & 10 & 11 & 5 & \\
\hline \multicolumn{5}{|c|}{ Inhibitory Control } \\
\hline EO & 5 & 21 & 0 & \multirow{2}{*}{$0.048^{*}$} \\
\hline EBO & 6 & 15 & 5 & \\
\hline
\end{tabular}

* Signifikan $p<0.05$ on the Pearson Chi-Square test. 


\section{STRADA Jurnal Ilmiah Kesehatan}

DOI: $10.30994 /$ sjik.v9i2.424

ISSN: 2252-3847 (print); 2614-350X (online)

Vol.9 No.2 November 2020 Page.1047-1055

Based on the Pearson Chi-Square test, Table 3 shows that there is no significant difference in the motor function of WBR Audio between the EO group and the EBO group $(\mathrm{p}=0.558)$, WBR Visual $(\mathrm{p}=0.918)$, balance $(\mathrm{p}=0.297)$, WM $(\mathrm{p}=0.636)$, while the executive function of IC showed a significant difference between the EO group and the EBO group $(\mathrm{p}=0.048)$.

\section{DISCUSSION}

The results of the examination of student identity data show an average age of 6.45 years, this age is in accordance with the Permendikbud curriculum regarding the rules for pre-school children aged 4-6 years (Kemendikbud, 2014), while according to the international curriculum the most adopted by countries around the world is Cambridge Syllabus. grouping preschool age 5-6 years (Igcse, 2014). The results of BMI data also show that the average is in the ideal category according to the BMI Table from WHO 14.0$16.6 \mathrm{~kg} / \mathrm{m}^{2}$ (WHO, 2007).

The link between children's participation in sports and the improvement of motor function has been carried out by many researchers and scientists who are engaged in the field of children. From the results of data analysis, it can be seen that there are differences between students who take extracurricular sports and those who are not sports, but the differences seen in the results above both WBR and balance are very weak and insignificant as shown by previous researchers and reviewers (Bürgi et al., 2011; Gao \& Wang, 2019; Stodden et al., 2008). However, there are several studies showing a significant correlation such as research conducted by Wrotniak et al. (2014) concluded that children with the highest motor skills were children who were physically active. In addition, children's participation in sports extracurricular activities in school also provides a good increase in children's motor function (Sportske et al., 2009).

Motor function in early childhood is very important to note, motor development is closely related to daily physical activity and children's participation in sports (Figueroa \& An, 2016). However, some of the children did physical activity and exercised less than the dose of exercise such as frequency, less intensity (Figueroa \& An, 2016) and the types of sports that were less varied, so they did not have less optimal motor function development.

Based on the results of the analysis of the WM executive function data in Table 2 and Table 3, it shows that there is no significant difference in the executive function of WM between the EO and EBO groups ( $>>0.05)$. These results are in line with the results of research conducted by Sjöwall et al. (2017) concluded that there was no significant difference in WM executive function between the control group and the exercise group after providing long-term exercise intervention for 2 years. However, based on the research of Kamijo et al. (2011) the effects of post-school exercise showed significant differences compared to the control group. Several other studies have also found a positive correlation between exercise and physical activity with the executive function of WM (Chen et al., 2014; Kamijo et al., 2011; de Greeff et al., 2018).

The results of the analysis of the mean inhibitory control (IC) in the EO group

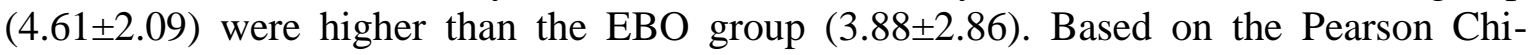
Square test, Table 3 shows that there is a significant difference in the executive function of IC between the EO group and the EBO group $(p=0.048)$. Chen et al 2014 said that exercise has an effect on inhibition and working memory in children (Chen et al., 2014).

Children who have a good level of fitness and regularly do physical activity have better basal ganglia and larger hippocampal capacity (Chaddock-Heyman et al., 2014). These two areas play a role in control inhibition and working memory (Chaddock-Heyman 


\section{STRADA Jurnal Ilmiah Kesehatan}

DOI: $10.30994 /$ sjik.v9i2.424

ISSN: 2252-3847 (print); 2614-350X (online)

Vol.9 No.2 November 2020 Page.1047-1055

et al., 2014; Neuroscience et al., 2013). The strength of the relationship depending on the frequency of training, intensity and type of sport is also very influential, such as tennis and football are correlated with the development of WM (Janssen et al., 2014).

\section{CONCLUSION}

Based on the results of the study, it can be concluded that there is no significant difference in motor function between students who take extracurricular sports and those who take non-sports extracurricular activities. However, students who took part in extracurricular sports in school had higher executive inhibitory control function than students who took non-sports extracurricular activities. Extracurricular sports in schools have a positive impact on executive functioning.

\section{REFERENCE}

Abramson, M. J., Benke, G. P., Dimitriadis, C., Inyang, I. O., Sim, M. R., Wolfe, R. S., \& Croft, R. J. (2009). Mobile telephone use is associated with changes in cognitive function in young adolescents. Bioelectromagnetics, 30(8): 678-686. https://doi.org/10.1002/bem.20534.

Adamo, K. B., Wilson, S., Harvey, A. L. J., Grattan, K. P., Naylor, P., Temple, V. A., \& Goldfield, G. S. (2016). Does Intervening in Childcare Settings Impact Fundamental Movement Skill Development?. Medicine \& Science in Sports \& Exercise, 35: 926-932. https://doi.org/10.1249/MSS.0000000000000838.

Barnett, L. M., Lai, S. K., Veldman, S. L. C., Hardy, L. L., Cliff, D. P., Morgan, P. J., \& Barnett, L. M. (2016). Correlates of Gross Motor Competence in Children and Adolescents : A Systematic Review and Meta-Analysis. Sports Medicine, 46(11): 1663-1688. https://doi.org/10.1007/s40279-016-0495-z.

Bellows, L. L., Davies, P. L., \& Anderson, J. (2013). Effectiveness of a Physical Activity Intervention for Head Start Preschoolers : A Randomized Intervention Study. Am J Occup Ther, 67(1):28-36. https://doi.org/10.5014/ajot.2013.005777.

Bürgi, F., Meyer, U., Granacher, U., Schindler, C., Marques-Vidal, P., Kriemler, S., \& Puder, J. J. (2011). Relationship of physical activity with motor skills, aerobic fitness and body fat in preschool children: A cross-sectional and longitudinal study (Ballabeina). International Journal of Obesity, 35(7): 937-944. https://doi.org/10.1038/ijo.2011.54

Chaddock-Heyman, L., Hillman, C. H., Cohen, N. J., Kramer, A. F., Chaddock-Heyman, L., Hillman, C. H., ... Kramer, A. F. (2014). The relation of childhood physical activity to brain health, cognition, and scholastic achievement: III. The importance of physical activity and aerobic fitness for cognitive control and memory in children. Monographs of the Society for Research in Child Development, 79(4): 25-50. https://doi.org/10.1111/mono.12129.

Chen, A. G., Yan, J., Yin, H. C., Pan, C. Y., \& Chang, Y. K. (2014). Effects of acute aerobic exercise on multiple aspects of executive function in preadolescent children. Psychology of Sport and Exercise, 15(6): 627-636. https://doi.org/10.1016/j.psychsport.2014.06.004.

de Greeff, J. W., Bosker, R. J., Oosterlaan, J., Visscher, C., \& Hartman, E. (2018). Effects of physical activity on executive functions, attention and academic performance in preadolescent children: a meta-analysis. Journal of Science and Medicine in Sport, 21(5): 501-507. https://doi.org/10.1016/i.jsams.2017.09.595.

Diamond, A. (2014). Executive Functions. Annu. Rev. Psychol, 64: 135-68 


\section{STRADA Jurnal Ilmiah Kesehatan}

DOI: $10.30994 /$ sjik.v9i2.424

ISSN: 2252-3847 (print); 2614-350X (online)

Vol.9 No.2 November 2020 Page.1047-1055

https://doi.org/10.1146/annurev-psych-113011-143750.

Epstein, H. T., \& Ma, U. S. A. (1986). Stages in human brain development. Developmental Brain Research, 30: 114-119.

Figueroa, R., \& An, R. (2016). Motor Skill Competence and Physical Activity in Preschoolers: Maternal and Child Health Journal, 21: 136-146. https://doi.org/10.1007/s10995-016-2102-1.

Gao, Z., \& Wang, R. (2019). Children's motor skill competence, physical activity, fitness, and health promotion. Journal of Sport and Health Science, 8(2): 95-97. https://doi.org/10.1016/j.jshs.2018.12.002.

Gibbs, J., Appleton, J., \& Appleton, R. (2007). Dyspraxia or developmental coordination disorder? Unravelling the enigma. Archives of Disease in Childhood, 92(6): 534539. https://doi.org/10.1136/adc.2005.088054.

Goldfield, G. S., Harvey, A., Grattan, K., \& Adamo, K. B. (2012). Physical Activity Promotion in the Preschool Years: A Critical Period to Intervene. International Journal of Environmental Research and Public Health, 9(4): 1326-1342. https://doi.org/10.3390/ijerph9041326.

Henry, L.A., \& Bettenay, C. (2010). The Assessment of Executive Functioning in Children. Child and Adolescent Mental Helath, 15(2): 110-119. https://doi.org/10.1111/j.1475-3588.2010.00557.x.

Igcse, C. (2014). Cambridge IGCSE ${ }^{\circledR}$ Child Development 0637. Available to: https://papacambridge.com/category/cie/sy-qp-ms/igcse/.

Janssen, M., Chinapaw, M. J. M., Rauh, S. P., Toussaint, H. M., Mechelen, W. Van, \& Verhagen, E. A. L. M. (2014). A short physical activity break from cognitive tasks increases selective attention in primary school children aged 10 e 11 . Mental Health and Physical Activity, 7(3): 129-134. https://doi.org/10.1016/j.mhpa.2014.07.001.

Kamijo, K., Pontifex, M. B., O’Leary, K. C., Scudder, M. R., Wu, C. T., Castelli, D. M., \& Hillman, C. H. (2011). The effects of an afterschool physical activity program on working memory in preadolescent children. Developmental Science, 14(5): 10461058. https://doi.org/10.1111/j.1467-7687.2011.01054.x.

Kemendikbud. (2014). Permendikbud No 146 Tahun 2014 tentang Kurikulum 2013 PAUD. 53(9): 1689-1699. https://doi.org/10.1017/CBO9781107415324.004.

Miyatake, N., Sakano, N., Yoshioka, A., Hirao, T., \& Numata, T. (2012). Evaluation of whole body reaction time and one leg with eye closed balance in elderly Japanese. $\begin{array}{llll}\text { Open Journal of } & \text { 22-27. }\end{array}$ https://doi.org/10.4236/ojepi.2012.21.004.

Neuroscience, H., Chaddock-heyman, L., Erickson, K. I., Voss, M. W., Knecht, A. M., Pontifex, M. B., \& Kramer, A. F. (2013). The effects of physical activity on functional MRI activation associated with cognitive control in children: a randomized controlled intervention. Front Hum Neurosci, 7(72): 1-13. https://doi.org/10.3389/fnhum.2013.00072.

Novkovic, T., Mittmann, T., \& Manahan-vaughan, D. (2015). BDNF Contributes to the Facilitation of Hippocampal Synaptic Plasticity and Learning Enabled by Environmental Enrichment. Hippocampus, 25(1): 1-15. https://doi.org/10.1002/hipo.22342.

Nyberg, F., \& Hallberg, M. (2013). Growth hormone and cognitive function. Nat Rev Endocrinol, 9(6): 357-365. https://doi.org/10.1038/nrendo.2013.78.

Pendidikan, M., Kebudayaan, D. A. N., \& Indonesia, R. (2014). PERMENDIKBUD No. 


\section{STRADA Jurnal Ilmiah Kesehatan}

DOI: $10.30994 /$ sjik.v9i2.424

ISSN: 2252-3847 (print); 2614-350X (online)

Vol.9 No.2 November 2020 Page.1047-1055

137. 13.

Permendikbud. (2014). Peraturan Menteri Pendidikan Dan Kebudayaan Republik Indonesia. https://doi.org/10.1017/CBO9781107415324.004.

Range, A., Childhood, E., Childhood, M., \& Setting, E. (2011). Interviewing Children \& Child Development.

Simpson, A., \& Riggs, K. J. (2005). Inhibitory and working memory demands of the daynight task in children. British Journal of Developmental Psychology, 23(3): 471486. https://doi.org/10.1348/026151005X28712.

Sjöwall, D., Hertz, M., \& Klingberg, T. (2017). No long-term effect of physical activity intervention on working memory or arithmetic in preadolescents. Frontiers in Psychology, 8: 1-10. https://doi.org/10.3389/fpsyg.2017.01342.

Sportske, I., Djece, A., Dobi, K., Motori, U. N. A., Postignuca, Caput-jogunica, T. P. R., \& Privitellio, S. De. (2009). Extracurricular sports activities in preschool children: impact on motor achievements and physical literacy. 82-87.

Stodden, D. F., Goodway, J. D., Langendorfer, S. J., Roberton, M. A., Rudisill, M. E., Garcia, C., \& Garcia, L. E. (2008). A Developmental Perspective on the Role of Motor Skill Competence in Physical Activity: An Emergent Relationship. Quest, 60(2): 290-306. https://doi.org/10.1080/00336297.2008.10483582.

WHO. (2007). Bmiaz for Boys Aged 2-5 Years. World Health Organization, 1-6. Retrieved from http://www.who.int/childgrowth/standards/bmi_for_age/en/.

Wrotniak, B. H., Epstein, L. H., Dorn, J. M., Jones, K. E., Kondilis, A., Wrotniak, B. H., \& Kondilis, V. A. (2014). The Relationship Between Motor Proficiency and Physical Activity in Children. Pediatrics, 118(6): e1758-e1765. https://doi.org/10.1542/peds.2006-0742.

Wu, M., Liang, X., Lu, S., \& Wang, Z. (2017). Infant Behavior and Development Infant motor and cognitive abilities and subsequent executive function. Infant Behavior and Development, 49(23): 204-213. https://doi.org/10.1016/j.infbeh.2017.09.005.

Zeng, N., Ayyub, M., Sun, H., Wen, X., Xiang, P., \& Gao, Z. (2017). Effects of Physical Activity on Motor Skills and Cognitive Development in Early Childhood: A Systematic Review. BioMed Research International, 2017: Article ID 2760716. https://doi.org/10.1155/2017/2760716. 